Historia Slavorum Occidentis

2021, nr 2 (29)

ISSN 2084-1213

DOI: $10.15804 /$ hso210205

Tomasz Kargol (Kraków)

ORCID:0000-0002-7195-6638

\title{
Zagłada ziemiaństwa polskiego na Ziemiach Zabranych w latach 1917-1921 na przykładzie rodziny Podhorskich
}

Keywords: Western Krai, landed gentry, the Podhorskis

\begin{abstract}
The article presents the history of the Podhorski family which, before 1914, owned numerous estates in Russian Ukraine. The family lost the estates following the October Revolution and the subsequent wars. Their fate was sealed by the Peace of Riga as a result of which, the Kiev region was incorporated into the USSR.
\end{abstract}

Rodzina Podhorskich przybyła do Polski w XVI w. jako emigranci polityczni z państwa moskiewskiego. Kniaź Hrehory (Hrihory) Podhorski poślubił córkę Hrihorego Tołmacz-Borkowskiego, właściciela znacznych dóbr na Wołyniu. Na początku XVIII w. w wyniku rodzinnych koligacji Podhorscy przenieśli się na Ukrainę ${ }^{1}$. Ród Podhorskich dzielił się na dwie gałęzie - starszą i młodszą. Gałąź starsza dzieliła się na dwie linie: lemieszczańską i korżowską. Nazwa pierwszej linii pochodzi od wioski Lemieszczycha $^{2}$ na Ukrainie. Gałąź młodsza, bereziańska, obejmowała właścicieli dóbr Berezna ${ }^{3}$

1 J. Wolff, Kniaziowie litewsko-ruscy od końca XIV wieku, Warszawa 1895, s. 386; T. Żychliński, Złota księga szlachty polskiej, Poznań 1892, t. 14, s. 13-16.

2 Lemieszczycha - wieś w powiecie taraszczańskim guberni kijowskiej. Słownik geograficzny Królestwa Polskiego i innych krajów słowiańskich (dalej SGKP), red. F. Sulimierski, B. Chlebowski, J. Krzywicki i W. Walewski, t. V, Warszawa 1884, s. 137.

3 Berezna - wieś w powiecie skwirskim w guberni kijowskiej; na początku XIX w. Jan Nepomucen Podhorski wybudował tu pałac klasycystyczny, który w latach osiemdziesiątych XIX w. został 
w powiecie skwirskim ${ }^{4}$. Ród uległ polonizacji i przeszedł do Kościoła rzymskokatolickiego. Po upadku Rzeczypospolitej władze rosyjskie pozbawiły Podhorskich tytułu książęcego i zaklasyfikowały ich do kategorii szlachty dziedzicznej ${ }^{5}$.

W XIX w. Podhorscy dzięki rodzinnym koligacjom i zakupom zgromadzili na Ukrainie znaczne dobra ziemskie. W zestawieniach najbogatszych rodzin ziemiańskich na Wołyniu, Podolu i Kijowszczyźnie, sporządzonych przez Tadeusza Epszteina, w 1849 r. Podhorscy zajmowali 26 miejsce z 4703 duszami, na przełomie zaś 1890 i 1891 r. - 21 miejsce na liście z 29396 dziesięcinami ziemi (dziesięcina=1,092 ha) ${ }^{6}$.

Na Kijowszczyźnie Podhorscy tworzyli „zamożny i zwarty ród ziemiański”. Posiadali dobra w powiatach skwirskim, taraszczańskim, berdyczowskim, lipowieckim i humańskim oraz na Wołyniu, Podolu i w guberni chersońskiej. Wedle ustaleń Piotra Podhorskiego na przełomie XIX i XX w. do 17 przedstawicieli rodu należało prawie 70000 dziesięcin ziemi. Dysponowali oni następującymi dobrami: Berezna (Stefan Podhorski, 4650 dziesięcin), klucz daszowski i Rude Sioło ${ }^{8}$ (Zofia z Rzewuskich Podhorska ${ }^{9}$, żona Stefana, 30000 i 1500 dziesięcin), Koneła ${ }^{10}$, Lemieszczy-

przebudowany; ostatnim właścicielem Berezny był Stefan Podhorski. SGKP, t. I, Warszawa 1880, s. 142; A. Urbański, Z Czarnego Szlaku i tamtych rubieży, Warszawa 1928, s. 115-118; R. Aftanazy, Materiaty do dziejów rezydencji, red. A.J. Baranowski, t. XIa, Warszawa 1993, s. 18-25.

4 T. Żychliński, Złota księga szlachty, s. 18-21.

5 B. Podhorski, Pogrom dworu, Karta 41 (2004), s. 23. Więcej na temat genealogii rodziny Podhorskich zob. Monografia rodu kniaziów Podhorskich ułożona przez Konstantego Podhorskiego, syna Oktawiana, Biblioteka Zakładu Narodowego im. Ossolińskich, (dalej BOss.), sygn. 16158/II (mf 29982), k. 1-21; T. Lenczewski, Genealogie rodów utytułowanych $w$ Polsce, t. I, Warszawa 1995-1996, s. 67-78.

6 T. Epsztein, Polska wtasność ziemska na Ukrainie w 1890 roku, Warszawa 2009, s. 35.

7 Klucz daszowski - kompleks dóbr w powiecie lipowieckim w guberni kijowskiej, którego głównych ośrodkiem było miasteczko Daszów, w XIX w. należał do Potockich (Włodzimierza Potockiego, syna Szczęsnego) i Podhorskich (Zofia z Rzewuskich Podhorska była prawnuczką Włodzimierza Potockiego). A. Urbański, Z Czarnego Szlaku, s. 119-122; SGKP, t. I, s. 908-910.

8 Rude Sioło - wieś w powiecie skwirskim guberni kijowskiej, ostatnią właścicielką była Zofia z Rzewuskich, żona Stefana Podhorskiego. SGKP, t. IX, s. 910; R. Aftanazy, Materiaty, s. 271-273 .

9 Zofia z Rzewuskich Podhorska (ok. 1876-1963) - córka Marii z Potockich i hr. Adama Rzewuskiego, Stefana Podhorskiego poślubiła w 1904 r. Po śmierci w 1908 r. jej brata Wacława Rzewuskiego na nią przeszły dobra Daszów, Podwysokie i Rude Sioło. R. Aftanazy, Materiały, s. 63.

10 Koneła - miasteczko w powiecie lipowieckim guberni kijowskiej, główny ośrodek kompleksu dóbr ziemskich. W 1857 r. Zygmunt Podhorski kupił Konełę od sukcesorów Władysława Przesmyckiego. SGKP, t. IV, s. 328-329. 
cha i Chinocze ${ }^{11}$ (Piotr Podhorski, odpowiednio 3000, 2000 i 7000 dziesięcin), Antonów ${ }^{12}$ (Ignacy Podhorski, 4700 dziesięcin), Lipki ${ }^{13}$ (Leon Podhorski, 1500 dziesięcin), Słobodyszcze ${ }^{14}$ (Władysław Podhorski, 2800 dziesięcin), Korżowa ${ }^{15}$ (Władysław Podhorski, 2000 dziesięcin), Iwachny ${ }^{16}$ (Stefan Podhorski, syn Leona, 1000 dziesięcin), Krzywiec ${ }^{17}$ (Witold Wilhelm Podhorski, 1200 dziesięcin), Łopa$\operatorname{tyn}^{18}$ (Baltazar Podhorski, syn Cezarego, 1200 dziesięcin), Dołoteckie ${ }^{19}$ (Cezary Podhorski i jego syn Stanisław, 1000 dziesięcin), Popówka (Witold Podhorski, syn Cezarego, 700 dziesięcin), Samhorodek i Buchny ${ }^{20}$ (Leon Podhorski, 600 i 900 dziesięcin), Rohacze (Rohaczew, Rohaczów) ${ }^{21}$ (Stefania Podhorska, żona Piotra, 600

11 Chinocz (Chinocze, Chinicze, Chinowicze, Chynocha, Hyncha) - wieś, folwark, kolonia na Polesiu, w międzywojennym powiecie sarneńskim województwa poleskiego. Skorowidz miejscowości Rzeczypospolitej Polskiej, t. VIII: Województwo Poleskie, Warszawa 1924, s. 65.

12 Antonów - wieś w powiecie skwirskim guberni kijowskiej, została nabyta w 1771 r. przez Michała Podhorskiego, zachowała się tam kaplica grobowa rodu Podhorskich. SGKP, t. I, s. 43; Kurier Galicyjski, wersja on-line https://kuriergalicyjski.com/historia/zabytki/8444-polskie-rezydencje-zytomierszczyzny-czesc-5 [dostęp: 3 VII 2020].

13 Lipki - wieś w powiecie skwirskim guberni kijowskiej, własność Podhorskich od $1850 \mathrm{r}$. SGKP, t. V, s. 268.

14 Słobodyszcze - miasteczko w powiecie żytomierskim guberni wołyńskiej.

15 Korżowa (Korżów) - wieś w powicie humańskim guberni kijowskiej, własność Potockich, Rafałowiczów, a potem Podhorskich. SGKP, t. IV, s. 438.

16 Iwachny - wieś w powiecie lipowieckim guberni kijowskiej, w XIX w. w połowie należała do Podhorskich, drugą część posiadali Rohozińscy. SGKP, t. III, s. 309.

17 Krzywiec - wieś w powiecie taraszczańskim guberni kijowskiej, znajdował się tam pałac zbudowany przez Kazimierza Podhorskiego. SGKP, t. IV, s. 807; Pocztówka z reprodukcją litografii przedstawiającej pałac w Krzywiecu zob.: https://fbc.pionier.net.pl/details/nnl36pc [dostęp: 2 VII 2020].

18 Łopatyn - wieś w powiecie berdyczowskim guberni kijowskiej, należała do Podgórskich, a potem do Baltazara Podhorskiego seniora (1873-1941). Znajdowały się tam kaplica i neogotycki pałac. A. Urbański, Z Czarnego Szlaku, s. 132-135; R. Aftanazy, Materiały, s. 168-169; Hoover Institution Library \& Archives, rysunek Mieczysława Jałowieckiego przedstawiający pałac w Łopatynie https://digitalcollections.hoover.org/objects/74340/opatyn-paac-ukraina-baltazar-podhorski;jsessionid=6FFD67F79AC00C0B0F066D9AFA4E0307?ctx=83708dc1-556c-456a-a7de-f816dfd8a99c [dostęp: 3 VII 2020].

19 Dołoteckie - własnością Podhorskich zostało na początku XIX w. Przedwojenni właściciele Cezary i Stanisław Podhorscy w 1914 r. ukończyli budowę nowego domu. A. Urbański, Podzwonne na zgliszczach Litwy i Rusi, Warszawa 1928, s. 85.

20 Buchny i Samhorodek - wsie w powiecie skwirskim guberni kijowskiej. SGKP, t. X, s. 248.

21 Rohacze - w latach 1872-1911 właścicielem Rohaczy był Wieńczysław Karnicki, następnie 
dziesięcin), Szlachowa ${ }^{22}$ (Józef Podhorski, 1500 dziesięcin), Faszczówka (Felicjan Podhorski, 1200 dziesięcin) ${ }^{23}$.

Mniejszą rolę rodzina Podhorskich odgrywała na Podolu. W 1849 r. w guberni podolskiej do przedstawicieli rodu należały majątki Atanazego Podhorskiego Mohylna (Mohilna), Salków i Zawale w powiecie hajsyńskim oraz Kuracze Łozy (Kurzęce Łozy) Edmunda Podhorskiego ${ }^{24}$.

W opinii Piotra Podhorskiego rodzina Podhorskich była jedną z najliczniejszych na Ukrainie, liczącą w 1900 r. 33 mężczyzn rozproszonych po całej Ukrainie i o dużym potencjale ekonomicznym, mimo to

nie stanowiła jednak jednolitej zwartej społeczności rodzinnej. Wszyscy się znali i spotykali, ale wobec dużych przestrzeni nie wszyscy mogli utrzymywać regularne relacje towarzyskie. Poza tym Podhorscy z reguły nie żenili się w rodzinie, nawet dalszej, a pobierali się z osobami z różnych rodzin, co w wyniku decydowało, że każdy dom miał swoją specyficzną cechę - raczej narzuconą przez panie wchodzące do rodziny ${ }^{25}$.

Na terenie Ukrainy Podhorscy podejmowali typowe dla ziemiaństwa akcje społeczne. Przede wszystkim byli zaangażowani w działalność towarzystw rolniczych. Władysław Podhorski z Korżowej pełnił funkcję prezesa Towarzystwa Rolniczego w Humaniu. W latach 1912-1914 był członkiem honorowym Towarzystwa i delegatem na zjazd przedstawicieli towarzystw rolniczych Podola, Wołynia i guberni kijowskiej w Kijowie ${ }^{26}$. Członkami zarządu Towarzystwa Rolniczego w Humaniu byli także Stefan Podhorski i Wacław Podhorski, a szeregowymi członkami: Bolesław Podhorski z Kalnika w powiecie humańskim, Piotr Podhorski z Lemieszczychy w powiecie lipowieckim, Stefan Podhorski z Iwachny w powiecie lipowieckim, Cezary Potocki z Dołoteckiego w powiecie berdyczowskim, Stefan Podhorski z Bereźnej w powiecie skwirskm, Witold Podhorski z Krzywiec w powiecie lipowiec-

jego siostra Julianna z Karnickich Iwaszkiewiczowa, a po niej jej wnuczki Zofia Lipska i Stefania z Dunin-Borkowskich Podhorska, żona Piotra Podhorskiego. R. Aftanazy, Materiaty, s. 257-261.

22 Szlachowa - wieś w powiecie jelisawietgradzkim w guberni chersońskiej.

23 Uzupetnienia do Monografii Rodziny Podhorskich zebrane przez Piotra Podhorskiego dnia 17.II.1960, BOss., sygn. 16158/II (mf 29982), k. 54.

24 T. Epsztein, Wielka własność ziemska $w$ guberni podolskiej w pierwszej połowie XIX wieku, Warszawa 2017, s. 258-259, 291.

25 P. Podhorski, Moje wspomnienia [z lat 1893-1965] na pamiątkę od ojca dla córek Marii $i$ Tereski, BOss., t. 1, rękopis, sygn. 15657/II (mf 88448), k. 111.

26 Tamże, s. 112. 
kim, Zygmunt Podhorski z Lemieszczychy i Piotr Podhorski z Buchny w powiecie skwirskim ${ }^{27}$.

Podhorscy nie stronili też od aktywności politycznej, kandydując do Dumy Państwowej. W 1906 r. w guberni kijowskiej wybrano Polaka, ziemianina Stanisława Syroczyńskiego, a na jego zastępcę Władysława Podhorskiego. W 1910 r. ten ostatni startował w prawyborach, które miały wyłonić polskiego kandydata, ale otrzymał tylko jeden głos ${ }^{28}$. W wyborach z $1910 \mathrm{r}$. na listach wyborców z biernym i czynnym prawem wyborczym w guberni kijowskiej znajdowało się kilku przedstawicieli rodu Podhorskich: w powiecie skwirskim Stefan Podhorski, Ignacy Podhorski (Łagwin), Leon Marcin Podhorski (Samhorodek), Leon Urban Podhorski (Lipki); w powiecie humańskim Władysław Podhorski (Korżowa), Leon Podhorski (Krzywiec), Stanisław Podhorski (Dołoteckie), Leon Podhorski (Brodeckie); w powiecie lipowieckim Piotr Podhorski (Lemieszczycha); w powiecie taraszczańskim Piotr Podhorski (Horoszków) ${ }^{29}$.

Przedstawiciele rodu Podhorskich przejawiali też charakterystyczne dla polskiego ziemiaństwa kresowego zainteresowania (łowiectwo, podróże, sztuka). Przejawem sympatii artystycznych było goszczenie znanych artystów. Kilkakrotnie na Ukrainie bawił m.in. Leon Wyczółkowski. Przebywał najdłużej w Bereznej u Kazimierza Podhorskiego, ale przyjmowany był także przez jego brata Michała oraz bratanków Władysława i Stefana. W Bereznej Wyczółkowski namalował obraz Woły. W 1912 r. artystę gościł przez kilka tygodni Zygmunt Podhorski i jego wnuk Wacław. Razem z Wyczółkowskim do Podhorskich przyjechał Tadeusz Cybulski, jego uczeń, malarz i rzeźbiarz. Nieco później do Koneły przybył Jerzy Warchałowski, teoretyk i krytyk sztuki, propagator sztuki stosowanej i ludowej. Wacław Podhorski cenił sobie znajomość z Leonem Wyczółkowskim, który pozostawił Podhorskim kolekcję obrazów, przepadłą niestety w czasie pierwszej wojny światowej i rewolucji w Ro$\mathrm{sji}^{30}$. Koneła i pobyt Wyczółkowskiego przykuły uwagę Jarosława Iwaszkiewicza, przebywającego tam kilka lat później:

\footnotetext{
27 Tamże, s. 113.

28 Kronika, Dziennik Kijowski, 18 IV (1 V) 1906, nr 63, s. 2; R. Jurkowski, Ziemiaństwo polskie Ziem Zabranych w wyborach do Dumy Państwowej i Rady Państwa 1906-1913, Olsztyn 2009, s. 342, 416.

29 Wybory do Rady Państwa, Dziennik Kijowski, 22 VIII (4 IX) 1910, nr 219, s. 1-2.

30 T. Epsztein, Z piórem i paletą. Zainteresowania intelektualne i artystyczne ziemiaństwa polskiego na Ukrainie $w$ II pot. XIX w., Warszawa 2005, s. 305-307.
} 
Taka była Koneła. Z dworu rozciągał się szeroki widok na wieś nad stawem, $\mathrm{z}$ drewnianą cerkiewką pośrodku. Widok ten stał się dla mnie czymś bardzo osobistym, ponieważ towarzyszy mi od dawna w postaci litografii Wyczółkowskiego, umieszczonej zawsze w pobliżu mojego pokoju, tak że od czasu do czasu mogę rzucić nań okiem. W pustym konelskim domu właśnie najbardziej zwróciły moją uwagę te akwaforty wielkiego malarza wiszące w hallu. Wyobrażone na nich widoki wsi i dworu w Konele, pejzażu i nastroje ukraińskie powstały w tym domu, w sercu Ukrainy, w domu Podhorskich ${ }^{31}$.

Owocem pobytu Wyczółkowskiego było powstanie cyklu litografii z panoramą Koneły oraz obrazu olejnego Krajobraz ukraiński (Panorama Koneły), znajdującego się obecnie w zbiorach Muzeum Narodowego w Krakowie ${ }^{32}$.

Celem artykułu nie jest omówienie dziejów rodu Podhorskich w XIX i XX w., ale zaprezentowanie ich losów w burzliwym czasie pierwszej wojny światowej, dwóch rewolucji i wojny domowej w Rosji oraz wojny polsko-bolszewickiej, które przyniosły kres obecności polskiego ziemiaństwa na ziemiach położonych na wschód od granicy ryskiej. Podstawą źródłową artykułu są wspomnienia Piotra Podhorskiego, Zygmunta Podhorskiego, trzy wspomnienia jego brata Wacława Podhorskiego oraz Bolesława Podhorskiego. Pominięto natomiast pamiętnik kolejnego przedstawiciela rodziny Podhorskich, Konstantego Podhorskiego ${ }^{33}$, ponieważ kończy się on na roku $1904^{34}$.

31 J. Iwaszkiewicz, Książka moich wspomnień, Poznań 2010, s. 138-139.

32 Zbiory cyfrowe Muzeum Narodowego w Krakowie, https://zbiory.mnk.pl/pl/wyniki-wyszukiwania?phrase=kone\%2525C5\%252582a [dostęp: 3 VII 2020].

33 Konstanty Podhorski (1859-1907) był synem Oktawiana Jana Udalryka Podhorskiego, urodzonego w Lemieszczysze w powiecie taraszczańskim w 1817 r., absolwenta pijarskiej szkoły w Winnicy, właściciela ziemskiego, hodowcy koni arabskich. Konstanty Podhorski był właścicielem dóbr Mikołajówka na Kijowszczyźnie, autorem prac genealogicznych o rodzie Podhorskich, wspomnień oraz relacji z podróży publikowanych na łamach „Dziennika Kijowskiego” w 1908 r., zatytułowanych Po obu stronach Cieśniny Beringa, gdyż jako podróżnik przebywał na Półwyspie Czukockim i Alasce. W 1906 r. przekazał Muzeum Narodowemu w Krakowie kilkadziesiąt eksponatów, przede wszystkim odzieży, związanych z ludem Czukczów. K. Podhorski, Ot, tak sobie, dla pamięci, czyli urywki z żywota nie sławnego człowieka, Archiwum Zamku Królewskiego w Warszawie, nr zespołu 112 (R XX), s. 3; biogram K. Podhorskiego na stronie Muzeum Etnograficznego w Krakowie, https://etnomuzeum.eu/syberia/darczynca/konstanty-podhorski [dostęp: 31 III 2020].

34 Zbiory rękopisów $w$ bibliotekach i muzeach $w$ Polsce, oprac. D. Kamolowa przy współudziale T. Sieniateckiej, Warszawa 2014, s. 437; Informator o zasobie Archiwum Zamku Królewskiego $w$ Warszawie - Muzeum, red. B. Gadomska, Warszawa 2018, s. 34. 
Pierwszy z pamiętnikarzy, Piotr Podhorski (1889-1970), urodził się w Samhorodku i był synem Leona Podhorskiego. W 1908 r. ukończył gimnazjum nr 5 w Kijowie, a następnie udał się na studia wyższe do Krakowa. W 1911 r. ukończył Studium Rolnicze na Uniwersytecie Jagiellońskim ${ }^{35}$. W tym samym roku podjął służbę wojskową w armii rosyjskiej. W 1912 r. przejął od ojca w administrację majątki Buchny i Rohaczew. W latach 1913-1914 wakacje u Piotra Podhorskiego w Samhorodku spędzał malarz Eugeniusz Kazimierowski. Malarz ten wykonał dla rodziny kilka prac: portret matki Piotra Podhorskiego, jego ojca oraz dwa portrety Walerii, drugiej żony ojca Piotra Podhorskiego, a także prace krajobrazowe ${ }^{36}$. Piotr Podhorski uczestniczył w pracach Polskiego Komitetu Wyborczego ${ }^{37}$. W latach 1910-1913 był prezesem polskiego klubu o nazwie „Ogniwo”, funkcjonującego w Kijowie ${ }^{38}$. Działał również w Towarzystwie Rolniczym Humańsko-Lipowieckim ${ }^{39}$. Za swoją działalnośći osobiste cechy charakteru Piotr Podhorski był ceniony w kresowym środowisku ziemiańskim ${ }^{40}$.

Dwaj kolejni pamiętnikarze, Wacław i Zygmunt Podhorscy, należeli do linii lemieszczańskiej. Ich dziadkiem od strony ojca był Jan Aleksander Zygmunt Podhorski (1826-1913), występujący w literaturze i pamiętnikach tylko pod imieniem Zygmunt, postać znana i opisywana przez pamiętnikarzy. Był on synem Konstantego Podhorskiego, właściciela Lemieszczychy, i mężem Marii Czarnkowskiej (zm. $1890)^{41}$. Zygmunt Podhorski był sędzią pokoju powiatu humańskiego z wyboru obywateli, członkiem komitetu włościańskiego w 1862 r. i tzw. pośrednikiem, urzędnikiem do przeprowadzenia reformy uwłaszczeniowej w powiecie taraszczańskim ${ }^{42}$. Dziadkowie Zygmunta i Wacława Podhorskich od strony matki, Benedykt Lipkowski z żoną Katarzyną z Kosowskich, mieszkali w Horodnicy. Mieli pięcioro dzieci: dwie córki i trzech synów - Benedykta, Jerzego i Serafina ${ }^{43}$.

\footnotetext{
35 Archiwum Uniwersytetu Jagiellońskiego, Studium Rolnicze, sygn. SR 52, 65.

36 P. Podhorski, Moje wspomnienia, t. 1, s. 108.

37 A. Iwański senior, Pamiętnik 1832-1876, A. Iwański junior, Wspomnienia 1881-1939, słowo wstępne J. Iwaszkiewicz, oprac. W. Zawadzki, Warszawa 1968, s. 377.

38 T. Epsztein, Z piórem i z paletą, s. 429; M. Korzeniowski, Za Złotą Bramą. Działalność społeczno-kulturalna Polaków w Kijowie w latach 1905-1920, Lublin 2009, s. 368.

39 P. Podhorski, Moje wspomnienia, t. 1, k. 113.

40 K. Podhorski, Ot, tak sobie, s. 149.

41 A. Iwański senior, Pamiętnik, s. 456.

42 Tamże, s. 157-158.

43 W. Podhorski, Ziemiaństwo na Ukrainie, Biblioteka Jagiellońska (dalej BJ), rękopis, sygn. 9831, s. 103-105; T. Żychliński, Złota księga, t. 14, s. 19.
} 
Zygmunt Podhorski miał syna Piotra Stefana Bonifacego Podhorskiego (1859-1916), ożenionego z Klementyną z Lipkowskich (1865-1941). Piotr Podhorski doczekał się trzech synów: najstarszego Włodzimierza Zygmunta Benedykta (1884-1941), średniego Wacława (1885-1966) i najmłodszego Zygmunta (1891-1960), późniejszego generała Wojska Polskiego.

Piotr Podhorski był ceniony w kręgach polskiego ziemiaństwa na Ukrainie. Jak wspominał August Iwański junior:

Syn pana Zygmunta, Piotr, z żoną i rodziną zamieszkiwał w pobliskiej Lemieszczysze, w małym, ale wychuchanym i wycackanym jak bombonierka dworze, w otoczeniu niewielkiego, ale miłego ogrodu. O porządek i ład w obejściu dbała pani Piotrowa, Lipkowska z domu, moja cioteczna siostra. Oboje Podhorscy byli mili i gościnni, toteż pobyt ich w domu był zawsze przyjemny. Piotr Podhorski łączył w sobie wielkopańskie narowy i przyzwyczajenia z głębokimi walorami umysłowymi i moralnymi, toteż był powszechnie szanowany, lubiany i wysuwany na czoło ziemiaństwa ${ }^{44}$.

Do 1892 r. rodzice Włodzimierza, Zygmunta i Wacława Podhorskich mieszkali w Popudni. W 1892 r. przenieśli się do Koneły ${ }^{45}$. W majątku Lemieszczycha zamieszkali dwa lata później. Sam Wacław Podhorski, kiedy osiągnął pełnoletność, zamieszkał w dawnej siedzibie rodziców - w majątku Koneła. Mieszkał tam ze swym dziadkiem aż do wybuchu rewolucji w Rosji ${ }^{46}$. Na przełomie XIX i XX w. w rękach rodziny Włodzimierza, Zygmunta i Wacława Podhorskich znajdowały się dwa majątki na Ukrainie: Lemieszczycha i Koneła. Trzecim majątkiem w jej posiadaniu były dobra ziemskie na Polesiu, nabyte przed pierwszą wojną światową. Miały one być „ekwiwalentem” dla dwóch sched na Ukrainie. Jeden z braci Wacława Podhorskiego zgodził się tam zamieszkać. Sam Wacław Podhorski nie chciał się tam przeprowa-

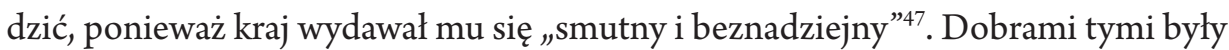
majątki Chinocz i Radyżów (Radyczów). W 1913 r. jako ich właściciele figurowali Włodzimierz, Wacław i Zygmunt Podhorscy ${ }^{48}$.

\footnotetext{
44 A. Iwański senior, Pamiętnik, s. 380.

45 W. Podhorski, Ziemiaństwo na Ukrainie, s. 138.

46 Tenże, Moje ostatnie wspomnienia, cz. I: Okres przedwojenny, BJ, rękopis, sygn. 9832, s. 25-28.

47 Tamże, s. 230.

48 T. Epsztein, Polska wtasność, s. 396-397.
} 
Wacław Podhorski (1885-1965) uczył się w Odessie ${ }^{49}$. Ukończył tam szkołę średnią, a następnie podjął studia prawnicze na tamtejszym uniwersytecie ${ }^{50}$. W wieku 21 lat, jeszcze w trakcie studiów, otrzymał od ojca plenipotencję do administrowania rodzinnymi dobrami (1907). Na stałe osiadł w nich po ukończeniu edukacji. W 1909 r. ojciec przekazał mu prowadzenie wszystkich interesów i mianował go kuratorem nad niepełnoletnim jeszcze młodszym bratem ${ }^{51}$. Wacław Podhorski w latach 1909-1914 zajmował się prowadzeniem majątku ziemskiego i sprawami rodzinnymi. Reprezentował ojca w konsorcjum dla ratowania zadłużonych dóbr Berezna po śmierci ich właścicieli Kazimierza i Michała Podhorskich oraz w sprawowaniu kurateli nad ich właścicielem - Stefanem Podhorskim, kuzynem Wacława ${ }^{52}$. W ocenie Zygmunta Podhorskiego jego brat Wacław był:

Inteligentny, o dużym dowcipie, zdolny, nie bardzo pracowity, lubił towarzystwo i był poszukiwany w towarzystwie, zwłaszcza jako myśliwy, bo był doskonałym strzelcem. Był estetą, dbał o swój wygląd i dobór rzeczy osobistych, lubił też dzieła sztuki i sam był uzdolnionym rysownikiem umiejąc znakomicie podpatrzeć podobizny, które utrwalał w starannie narysowanych karykaturach. Później przerzucił się na miniatury na kości słoniowej ${ }^{53}$.

Mimo młodego wieku, Wacław Podhorski ceniony był jako dobry gospodarz, o czym świadczy to, że Kijowskie Towarzystwo Rolnicze kierowało praktykantów (uczniów kursów rolniczych) do jego dóbr ${ }^{54}$. Działał również w Humańsko-Lipowieckim Towarzystwie Rolniczym ${ }^{55}$.

49 Odessa była popularnym w kręgach polskiego ziemiaństwa z Ziem Zabranych, zwłaszcza z Podola i Ukrainy, ośrodkiem dydaktycznym. Funkcjonowało tam gimnazjum, szkoła handlowa i Impieratorskij Noworossijskij Uniwiersitiet założony w 1865 r. Popularność Odessy wynikała z panującej tam liberalniejszej atmosfery, bliskości miasta, związków społeczno-gospodarczych z Podolem i Kijowszczyzną. Tamtejsi ziemianie w Odessie posiadali swoje nieruchomości i rezydencje, mieli udziały w odeskich przedsiębiorstwach. W 1903 r., czyli w epoce, kiedy studiował tam Wacław Podhorski, nauki na uniwersytecie pobierało 90 Polaków. T. Epsztein, Edukacja dzieci i młodzieży w polskich rodzinach ziemiańskich na Wołyniu, Podolu i Ukrainie w II potowie XIX wieku, Warszawa 1998, s. 77, 93, 95.

50 W. Podhorski, Moje ostatnie wspomnienia, s. 154.

51 Tamże, s. 32.

52 Tamże, s. 33-40.

53 Z. Podhorski, Wspomnienia generała Zygmunta Podhorskiego. Fragmenty wybrane, Pamiętnik Kijowski 4 (1980), s. 69-70.

54 W. Podhorski, Moje ostatnie wspomnienia, s. 41.

55 Uzupetnienia do Monografii, k. 56. 
Młodszy brat Wacława, Zygmunt Podhorski (1891-1960), w latach 1903-1909 uczył się w Warszawie w cenionej szkole handlowej Edwarda Rontalera, chociaż początkowo rodzice planowali, aby kształcił się w Odessie, śladem swoich braci ${ }^{56}$. W szkole Rontalera studiował na wydziale rolniczym. Naukę kontynuował w Krakowie w Studium Rolniczym w latach 1910-1914 ${ }^{57}$.

Czwarty z pamiętnikarzy, Bolesław Podhorski (1896-1979) był synem Józefa Jana i Marii Kazimiery z Malczewskich, właścicieli majątku Szlachowa w powiecie jelisawietgradzkim w guberni chersońskiej ${ }^{58}$. Dzieciństwo i młodość spędził w rodzinnym majątku, a następnie podjął naukę w szkole Rontalera w Warszawie na wydziale rolnym. Ukończył ją w 1913 r., ale kontynuował edukację na Kursach Przemysłowo-Rolniczych Józefa Mikołuskiego-Pomorskiego w Warszawie, którą przerwał w 1915 r. i powrócił do domu ${ }^{59}$.

Pamiętniki Piotra Podhorskiego, zatytułowane „Moje Wspomnienia na pamiątkę od ojca dla córek Marii i Tereski” znajdują się w zbiorach Biblioteki Zakładu Narodowego im. Ossolińskich (sygn. 15657). Fragmenty tego pamiętnika ukazały się na łamach „Wiadomości Ziemiańskich” w opracowaniu profesora Tadeusza Epszteina, który przygotowuje ich pełną edycję źródłową ${ }^{60}$.

Wspomnienia Wacława Podhorskiego są przechowywane w Bibliotece Jagiellońskiej. „Ziemiaństwo na Ukrainie” (rękopis nr 9831) składa się z dwudziestu rozdzialów noszących następujące tytuły: „Słowo wstępne”, „Charakterystyka kraju i ludzi”, „Podział ziemiaństwa na grupy”, „Charakterystyka opisanych czasów”, „Wychowanie”, „Życie codzienne”, „Szkolnictwo”, „Stosunek do Rosjan i praca społeczna”, „Nasze siedziby”, „Obyczaje i codzienne życie”, „Życie towarzyskie”, „Myślistwo”, „Życie gospodarcze i ekonomiczne”, „Ewolucja w życiu ziemiaństwa”, „Kontrakty Kijowskie”, „Sprawy duchowe”, „Ziemiaństwo i kler”, „Ziemiaństwo innych dzielnic”, „Okres 1905-1914”, „Rok 1914”. Na stronie tytułowej maszynopisu widnieje autograf pamiętnikarza i data „marzec 1963”, oznaczająca zapewne czas ukończenia pisania wspomnień.

„Moje wspomnienia łowieckie” (rękopis nr 9830) również zostały spisane w 1963 r. na maszynopisie z odręcznymi poprawkami. Tworzą je dwie części:

\footnotetext{
56 Z. Podhorski, Wspomnienia generata, s. 51-52.

57 Archiwum UJ, Studium Rolnicze, sygn. SR 53-55.

58 B. Podhorski, Pogrom dworu, s. 23; M. z Podhorskich Reyowa, A. Rey, Podhorski Józef Jan, [w: Ziemianie polscy XX wieku. Stownik biograficzny, cz. 6, Warszawa 2002, s. 113.

59 Tamże, s. 116.

60 P. Podhorski, Pamiętnik z Ukrainy z przełomu XIX i XX wieku, Wiadomości Ziemiańskie 71 (2017), s. 50-65.
} 
„Ukraina” do 1914 r. oraz „Polesie” dla okresu międzywojennego. W części pierwszej Podhorski zawarł własne ogólne rozważania na temat łowiectwa, zamieścił swoje trzy artykuły opublikowane na łamach „Łowca Polskiego” w latach 1936-1937 oraz swe wspomnienia z „lat dziecinnych” i „lat dojrzałych”. Część druga ma układ chronologiczno-tematyczny. Najpierw Podhorski opisał swoje wspomnienia $\mathrm{z}$ „okresu przejściowego”, czyli lat między wybuchem Wielkiej Wojny a osiedleniem się na Polesiu na początku lat dwudziestych, a następnie polowania na wilki, dziki, głuszce i drobną zwierzynę. Natomiast „Moje ostatnie wspomnienia. Część I. Okres przedwojenny" (rękopis nr 9832 III) zostały spisane w latach 1964-1965 i były ostatnim tekstem napisanym przez Podhorskiego. Dzieliły się na dwie części. Pierwsza obejmowała okres do zakończenia pierwszej wojny światowej, druga zaś lata międzywojenne. Wacław Podhorski wspominał o czwartym swoim tekście pt. „Zmierzch polskości na Kresach/Rusi”, którego nie udało się zidentyfikować. Wspomnienia Wacława Podhorskiego nie były dotychczas publikowane, ani w całości, ani we fragmentach, natomiast były znane badaczom dziejów ziemiaństwa na Ziemiach Zabranych, korzystających przede wszystkim z „Ziemiaństwa na Ukrainie" ${ }^{61}$. Wspomnienia Bolesława Podhorskiego Pogrom dworu zostały opublikowane wpierw na łamach „Karty” w 2004 r. $^{62}$, a następnie w antologii ziemiańskich wspomnień zatytułowanej Czas ziemiaństwa ${ }^{63}$. Z kolei wyjątki ze wspomnień Zygmunta Podhorskiego zostały wydane w różnych publikacjach na emigracji i w Polsce ${ }^{64}$.

61 D. Beauvois, Trójkąt ukraiński. Szlachta, carat i lud na Wotyniu, Podolu i Kijowszczyźnie 1793-1914, tłum. K. Rutkowski, Lublin 2005; M. Ustrzycki, Ziemianie polscy na Kresach 1864-1914, Świat wartości i postaw, Kraków 2006.

62 B. Podhorski, Pogrom dworu, s. 22-31.

63 Czas ziemiaństwa, wybór i opracowanie tekstów A. Richter, Warszawa 2017.

64 Z. Podhorski, Wspomnienia generała, s. 39-88; Społeczeństwo polskie na Ukrainie wobec wydarzeń politycznych $w$ Rosji, Pamiętnik Kijowski 4 (1980), s. 153-161; Ze wspomnień generata Zygmunta Podhorskiego, wstęp i wyd. K. Krzeczunowicz, Przegląd Kawalerii i Broni Pancernej 14 (1982), nr 105/106, s. 1-14; Ziemie ruskie tzw. prowincje zabrane Rzeczypospolitej w latach 1900-1914, Pamiętnik Kijowski 5 (1995), s. 21-36; O niektórych parafiach i powiatach, tamże, s. 21-36; Wspomnienia dowódcy 203 Pułku Ułanów z walk o Ciechanów w 1920 roku, Wojskowy Przegląd Historyczny 4 (1996), s. 208-214; Moja Ukraina i moje Chinocze, oprac. A. Suchcitz, [w:] Europa nieprowincjonalna. Przemiany na ziemiach wschodnich dawnej Rzeczypospolitej (Białoruś, Litwa, Łotwa, Ukraina, wschodnie pogranicze III Rzeczypospolitej) w latach 1772-1999, red. K. Jasiewicz, Warszawa-Londyn 1999, s. 521-535; Pamiętniki i listy polskich autorów $z$ Ziem Zabranych (Litwa, Białoruś, Ukraina) w latach 1795-1918. Materiały do katalogu, t. I: Pamiętniki rękopiśmienne i drukowane, oprac. i red. M. Domańska-Nogajczyk, T. Wójcik, W. Caban, L. Michalska-Bracha, Kielce 2017, s. 125, 186, 376. 
Fragmenty archiwów podworskich Podhorskich znajdują się w rękach prywatnych ${ }^{65}$.

W badaniach nad dziejami ziemiaństwa polskiego w XIX i XX w. pamiętniki samych ziemian należą do jednego z podstawowych rodzajów źródeł. Przynoszą wiele cennych informacji, a przy braku archiwaliów podworskich są niekiedy jedynym źródłem wiedzy o poszczególnych osobach, rodzinach lub majątkach. Pamiętać jednak należy, na co zwrócił uwagę prof. Witold Molik, że pamiętniki powinny być poddane przez historyka krytyce zewnętrznej i wewnętrznej ${ }^{66}$.

Podsumowując, dysponujemy wspomnieniami czterech Podhorskich, reprezentujących generację ziemian urodzonych w latach osiemdziesiątych-dziewięćdziesiątych XIX stulecia. Wacław Podhorski urodził się w 1885 r., Piotr Podhorski w 1889 r., Zygmunt Podhorski w 1891 r., a najmłodszy z nich Bolesław Podhorski w 1896 r. Ich pamiętniki zostały spisane w latach sześćdziesiątych XX w., kilka lat przed śmiercią autorów. Wspomnienia Piotra Podhorskiego „Moje wspomnienia na pamiątkę od ojca dla córek Marii i Tereski” spisane zostały prawdopodobnie w latach 1962-1966. Na ich tytułowej stronie widnieją dwie daty: 1962 i 8 II 1966. Ich autor zmarł w 1970 r. Wspomnienia Wacława Podhorskiego spisano w latach 1963 („Ziemiaństwo na Ukrainie” i „Moje wspomnienia łowieckie”), 1964-1965 („Moje ostatnie wspomnienie. Część I. Okres przedwojenny”), a ich autor zmarł w 1966 r. Natomiast Zygmunt Podhorski i Bolesław Podhorski swoje relacje zaczęli spisywać $w$ czasie pobytu w niemieckim obozie jenieckim podczas drugiej wojny światowej ${ }^{67}$. Analizowana memuarystyka powstała w czasie drugiej wojny światowej i ok. 20 lat po jej zakończeniu, w całkowicie odmiennych realiach historycznych, politycznych i społeczno-gospodarczych. Pamiętniki Podhorskich prezentują więc wydarzenia, zjawiska, osoby z perspektywy kilkudziesięciu lat. Wacław Podhorski swe ostatnie wspomnienia pisał w wieku 80 lat, jako człowiek schorowany (utrata wzroku), bez wykorzystania notatek, zapisków oraz jak to sam ujął:

65 T. Epsztein, Zbiory rękopisów podzielone i rozproszone na przykładzie kolekcji podworskich z Ukrainy - problemy archiwalne i edytorskie, [w: ] Polskie dziewiętnastowieczne pamiętniki i listy z Ziem Zabranych - rola i miejsce $w$ badaniach historycznych, red. W. Caban, L. Michalska-Bracha, Warszawa 2017, s. 92.

66 W. Molik, Stan badań nad dziejami ziemiaństwa na ziemiach polskich w okresie zaborów, [w:] Od zjazdu w Łodzi do zjazdu w Szczecinie. Bilans badań nad dziejami szlachty i ziemiaństwa na ziemiach polskich $w$ XIX wieku, red. K.A. Makowski i K. Karolczak, Warszawa 2017, s. 38-41.

67 Z. Podhorski, Wspomnienia dowódcy 203 Pułku, s. 8; B. Podhorski, Pogrom dworu, s. 22. 
bez żadnego z góry ustalonego planu, bez żadnego przestrzegania chronologii wypadków, ani związku między niemi. Notowałem nie tylko wydarzenia, których sam był świadkiem, ale także zasłyszane lub przeczytane epizody charakterystyczne dla opisywanej epoki. Nie biorę gwarancji za ich autentyczność, będę każdorazowo zaznaczać, czy opisywany fakt jest mi osobiście znany, czy też tylko zasłyszany ${ }^{68}$.

W efekcie, powtarzając znowu fragment wspomnień samego Wacława Podhorskiego, mamy do czynienia ze „zbiorem najrozmaitszych faktów, podań, plotek, anegdot, rozważań nad rozmaitymi aktualnymi zagadnieniami”69.

Żadne ze wspomnień nie powstały na Ziemiach Zabranych, a losy ziemiaństwa od drugiej połowy XIX w. po początek lat dwudziestych XX stulecia są opisywane z perspektywy dwóch wojen światowych, narodzin i upadku II Rzeczypospolitej, zmiany granic Polski po 1945 r., powstania Polski Ludowej. Spośród czterech pamiętnikarzy jedynie Zygmunt Podhorski zmarł na emigracji w Wielkiej Brytanii, pozostali żyli, spisywali swe wspomnienia i zmarli w PRL. Bolesław Podhorski powrócił do kraju z Anglii w 1958 r. W przypadku wspomnień Wacława Podhorskiego perspektywa krajowa jest bardzo widoczna w maszynopisie. Nawiązuje on do bieżącej sytuacji, porównuje ją do okresu swej młodości, operuje takimi pojęciami jak „kasta”, „chuligani” w odniesieniu o bałagułów.

We wspomnieniach Wacława Podhorskiego są widoczne językowe i ideologiczne wpływy epoki. Sam we wstępie do „Ziemiaństwa na Ukrainie” pisał o sobie, że pochodził ze „sfery obszarniczo-szlacheckiej”, podkreślał, iż przestała ona już „egzystować”, „przestała istnieć już od dawna”, „jest to karta bezpowrotnie zamknięta”70.

Wacław Podhorski swe prace traktował jako obiektywne, rzetelne omówienie ziemiaństwa kresowego. Miał świadomość, że władze komunistyczne starały się środowisko ziemiańskie - jak sam to określał - „zohydzić”, umieścić „na indeksie”, „wywlec na światło dzienne wszystkie ujemne strony”, „przemilczeć dodatnie”, ale nie stawiał sobie za cel przeciwdziałanie tej retoryce, nie chciał ziemiaństwa „oczyszczać z zarzutów”, „gloryfikować”71. Nie chciał też iść śladem Tadeusza Bobrowskiego ${ }^{72}$

\footnotetext{
68 W. Podhorski, Moje ostatnie wspomnienia, s. 2.

69 Tamże.

70 Tenże, Ziemiaństwo na Ukrainie, s. 2.

71 Tamże.

72 Podhorski ma tu na myśli wydane w 1900 r. pamiętniki Tadeusza Bobrowskiego, które wywołały wówczas skandal obyczajowy, oburzenie i protesty ziemian z Wołynia, Podola i Ukrainy. Więcej na ten temat zob. S. Kieniewicz, Przedmowa wydawcy, [w:] T. Bobrowski, Pamiętnik
} 
czy Kazimierza Chłędowskiego ${ }^{73}$, którzy w jego opinii „lubowali się w wywlekaniu spraw osobistych i najrozmaitszych z tem związanych brudów"74.

Kolejnym ważnym elementem, który należy przeanalizować, jest ustalenie przyczyn spisania wspomnień. Pierwszym i najważniejszym motywem było przygotowanie pamiętników dla dzieci, rodziny, kolejnych pokoleń. Piotr Podhorski zadedykował je swoim córkom, ale jeden maszynopis sprzedał Bibliotece Zakładu Narodowego im. Ossolińskich we Wrocławiu ${ }^{75}$.

Wacław Podhorski nie doczekał się potomstwa, a „Ziemiaństwo na Ukrainie” pisał nie dla jego pokolenia, ale dla przyszłych. Maszynopisy jego wspomnień zostały zakupione przez Bibliotekę Jagiellońską od nieistniejącego już krakowskiego antykwariatu przy ulicy Podwale.

Wymienione wyżej wspomnienia Podhorskich, zwłaszcza Zygmunta, Wacława i Piotra, są ze sobą kompatybilne, uzupełniają się. Dwaj pamiętnikarze, Zygmunt i Wacław, to przecież bracia, a Piotr to ich kuzyn. Wszyscy piszą o tych samych problemach, osobach i miejscach.

Kolejną grupę źródeł tworzą wydane drukiem ziemiańskie wspomnienia z czasów Wielkiej Wojny i rewolucyjnych zawieruch, a mianowicie: Marii Dunin-Kozickiej, Zofii Kossak-Szczuckiej, Elżbiety z Zaleskich Dorożyńskiej, Zofii z Zamoyskich Grocholskiej, Tadeusza Fabiańskiego. We wspomnieniach tych brak jednak informacji o rodzinie Podhorskich i jej losach w latach 1914-1921.

Ostatnim rodzajem źródeł jest prasa polska z lat 1917-1918. Informacje na temat pogromów ziemiańskich majątków w Rosji przynosiła ukazująca się tam polska prasa, na czele z „Dziennikiem Kijowskim”. Niestety, brak numerów tego ostatniego periodyku z przełomu lat 1917-1918, wymusił sięgnięcie do gazet galicyjskich („Gazeta Lwowska”, „Kurier Lwowski”, „Czas”, „Rolnik”), zawierających przedruki z „Dziennika Kijowskiego" i innych tytułów. W prasowych artykułach i komunikatach nie udało się jednak odnaleźć wzmianek o pogromach dworów i majątków Podhorskich.

Stabilizację ziemiańskiego życia na Ziemiach Zabranych przerwał wybuch pierwszej wojny światowej, a następnie rewolucje w Rosji, przewroty polityczne na Ukrainie, wojna domowa w Rosji, wojna polsko-ukraińska i wojna polsko-bolszewicka.

mojego $\dot{z} y c i a$, t. 1, opracował, wstępem i przypisami opatrzył S. Kieniewicz, Warszawa 1979, s. 5-21 .

73 Kazimierz Chłędowski (1843-1920) - pisarz, pamiętnikarz, polityk, minister dla Galicji w Austro-Węgrzech.

74 W. Podhorski, Moje ostatnie wspomnienia, s. 3.

75 T. Epsztein, Wprowadzenie, [w:] P. Podhorski, Pamiętnik z Ukrainy, s. 51. 
Po wybuchu pierwszej wojny światowej Zygmunt i Włodzimierz Podhorscy, bracia Wacława, zostali powołani do wojska ${ }^{76}$. Zygmunt w $1917 \mathrm{r}$. został przydzielony do 1. pułku ułanów Dywizji Strzelców Polskich (1. Pułku Ułanów Krechowieckich), walczył pod Krechowcami. Służbę w tej jednostce kontynuował w kolejnych latach, dowodził szwadronem, aż w 1920 r. został dowódcą pułku77. Wacław Podhorski, jak sam wspominał, „dekował się” przed powołaniem do armii czynnej i zgłosił się do wojsk inżynieryjnych. W 1917 r. jego jednostka stacjonowała w Czerniowcach na Bukowinie, a Podhorski pełnił służbę w Kamieńcu Podolskim, m.in. z zadaniem wysadzenia mostu na Dniestrze koła Żwańca. W 1917 r. jednostka Podhorskiego została ewakuowana do Mohylowa Podolskiego, ale on sam wyjechał do Kijowa ${ }^{78}$. W latach 1917-1918 brał udział w pracach Rady Ziemian w Kijowie, stowarzyszenia skupiającego elitę ziemiańską i zajmującego się rejestracją szkód w majątkach ziemskich. Zorganizował również Związek Rodzinny Podhorskich, aby udzielać pomocy członkom rodu. W $1920 \mathrm{r}$. liczył on 26 mężczyzn i 14 kobiet $^{79}$.

Bracia Zygmunt i Wacław Podhorscy oraz Piotr Podhorski w swych wspomnieniach nie informowali szczegółowo o losach swych majątków i rodzinnych siedzib. Nie podawali dat ani okoliczności utraty lub zniszczenia majątków na Ukrainie. Wacław Podhorski ogólnikowo pisał o „opuszczeniu ojczystego kraju” i „osiedleniu się” w Polsce ${ }^{80}$. Z kolej Zygmunt Podhorski dokonał ogólnej oceny tragicznych wydarzeń przełomu 1917 i $1918 \mathrm{r}$.:

Okres jesieni 1917 r. i zimy 1918 r., zwłaszcza w pasie przyfrontowym, był okresem ruiny zupełnej większej własności. Podżegaczami i prowodyrami rabunków i napadów na majątki i dwory byli przeważnie dezerterzy z rozpadającej się armii. Pociągali oni za sobą wieś, która chcąc nie chcąc przyłączała się do pogromów w obawie, że dla niej nic nie zostanie. Były to rabunki dzikie i bezmyślne, często okrutne i niosące śmierć, jak np. zamordowanie w Sławucie ks. Romana Sanguszki ${ }^{81}$. Straty materialne były ogromne, jak również straty kultu-

\footnotetext{
76 W. Podhorski, Moje ostatnie wspomnienia, s. 46.

77 A. Wojciechowski, Zarys historji wojennej 1-go pułku ułanów krechowieckich, Warszawa 1929, s. 22, 32.

78 W. Podhorski, Moje ostatnie wspomnienia, s. 68, 76.

79 Uzupetnienia do Monografii, k. 24, 55; P. Podhorski, Moje wspomnienia, t. 1, k. 163.

80 W. Podhorski, Moje ostatnie wspomnienia, s. 130.

81 E. Rzyszczewska, Egzekucja, Karta 41 (2004), s. 16-21; J. Długosz, Sanguszko Roman Damian (1832-10-17-1917-11-01), https://www.ipsb.nina.gov.pl/a/biografia/roman-damian-sanguszko [dostęp: 2 VII 2020].
} 
ralne w postaci zniszczonych i spalonych dzieł sztuk, bibliotek, archiwów rodzinnych, cennych zbiorów ${ }^{82}$.

Bohdan Hud w historii zagłady polskiej wielkiej własności ziemskiej na Ukrainie w latach 1917-1918 wyróżnił trzy fazy: pierwszą z kwietnia-czerwca 1917 r., drugą z lipca-września 1917 r. oraz trzecią od października 1917 r. do kwietnia 1918 r. ${ }^{83}$. W pierwszej fazie antyziemiańskie wystąpienia chłopów nie były jeszcze radykalne i intensywne. Przede wszystkim chłopi domagali się większego dostępu do ziemi, lasów i pastwisk. Żądania te nie stanowiły zagrożenia dla egzystencji polskiego ziemiaństwa ${ }^{84}$. Latem i jesienią 1917 r. nastąpiło zaostrzenie sytuacji na Kijowszczyźnie, Podolu i Wołyniu. Zaczęły powstawać chłopskie komitety, nasiliły się chłopskie strajki i rozruchy oraz przywłaszczenia ziemiańskiego zboża, a także grabieże majątków. Antyziemiańskie wystąpienia chłopstwa zostały na jakiś czas stłumione przez wojsko ${ }^{85}$. Jesienią $1917 \mathrm{r}$. na obszarze Ukrainy rozpoczą się pogrom polskich majątków. Został on zapoczątkowany przez zrewolucjonizowane oddziały wojskowe, za którymi ruszyli chłopi. Na początku października żołnierze zbolszewizowanego II Korpusu w trakcie przemarszu z okolic Kamieńca Podolskiego na Wołyń zniszczyli kilkadziesiąt majątków, dworów i zakładów przemysłowych ${ }^{86}$. W następnych miesiącach fala antyziemiańskich i antychłopskich wystąpień żołnierzy, dezerterów, rezerwistów i chłopów rozlała się na całe Prawobrzeże. Ich nasilenie przypadło na listopad i grudzień 1917 r. oraz pod koniec stycznia 1918 r. Do końca marca $1918 \mathrm{r}$. na Wołyniu, Podolu i Kijowszczyźnie $85 \%$ polskich majątków zostało ograbionych lub zniszczonych ${ }^{87}$.

Przypuszczać należy, że dobra Podhorskich na Kijowszczyźnie mogły zostać zniszczone w trakcie trzeciej fali chłopskich wystąpień na Ukrainie w październiku, listopadzie i grudniu 1917 r. lub na początku 1918 r. Zofia Kossak-Szczucka tak pisała o sytuacji na tych obszarach:

Z Kijowszczyzny nadchodziły wieści o ruchach agrarnych, coraz to groźniejszych. Straszliwe: Taraszcza, Skwira, Kaniów, Białocerkiew, mające hajdma-

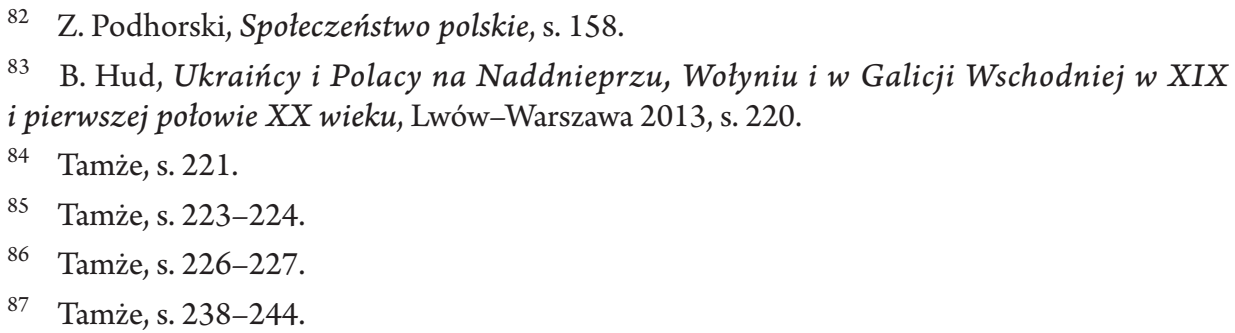


czyznę we krwi i tradycji, pierwsze, jak przed laty, podnosiły żagiew pogromów i rzezi ${ }^{88}$.

Relację tę potwierdzają wspomnienia Marii Dunin-Kozickiej:

Szły czarne szlaki zniszczenia przez jary podolskie i przez bory Wołynia, krzyżując się wielokrotnie na wszystkich skrętach przydrożnych, aż wreszcie dotarły do stepów ukrainnych... i rozbiegły się po całym taraszczańskim powiecie, [...] I dalej, dalej - przez Ryżawkę, Czerpowody, Kołodyste Iwańskich, przez Horodnicę i Zacisze Lipkowskich, przez Berstiahy Zakrzewskich, i w skwirskim powiecie z ziemią równały majątki Rzewuskich i Podhorskich, i innych, innych, a zawsze polskie ${ }^{89}$.

Z prasowych doniesień wynika, że w grudniu doszło do antyziemiańskich wystąpień w guberni kijowskiej, pisano o rozgromieniu majątku Antonówka ${ }^{90}$. Przez bolszewików zamordowany został jedyny syn Felicjana Podhorskiego z Bukryna Wielkiego w powiecie kaniowskim ${ }^{91}$. Dewastacji uległ dwór w Samhorodku i w Daszowie, a z nim dzieła sztuki ${ }^{92}$. W przypadku Podhorskich nie wszystkie majątki zostały spustoszone. Do 1920 r., kiedy to wojska polskie zajęły Ukrainę, dwory w Bochnach i Rohaczewie nie zostały ani zniszczone, ani zrabowane ${ }^{93}$.

W czasie pierwszej wojny i po rewolucji lutowej w Rosji polscy ziemianie przypuszczali, że tak jak w czasie rewolucji 1905 r., tak i wtedy uda się przetrwać kryzys. Przykładem takiego rozumowania jest fragment wspomnień Piotra Podhorskiego:

Chłop ukraiński, jak każdy rolnik mający mniej, uważał że ziemia winna być im rozdana, względnie sprzedana za nieznaczną kwotę. Niemniej uważali, że właścicielowi majątku też coś się należy, a do samych dworów-sadyb nie mieli żadnych zaborczych instynktów. Namiętności te rozbujała dopiero rewolucja. Rabunków dworów poza strefą przyfrontową do 1918 roku było stosunkowo mało ${ }^{94}$.

Z. Kossak-Szczucka, Pożoga. Wspomnienie z Wołynia 1917-1919, Rzeszów 1990, s. 21. 
W obliczu zagrożenia schronienia szukano najczęściej w większych miastach, np. w Winnicy i Kijowie. Bolesław Podhorski ostrzeżony przez miejscowych chłopów na początku 1918 r. wyjechał do Kijowa ${ }^{95}$. Tak wspominał tę sytuację:

Gdy odjeżdżałem z domu pełnego gości, uwolnionego w naszym pojęciu od bezpośredniego niebezpieczeństwa, przypuszczaliśmy, że szczęśliwie przetrwaliśmy tę rewolucję i że podobnie jak w 1905 roku Szlachowa ocaleje od pogromu ${ }^{96}$.

Bolesław Podhorski postawę miejscowych chłopów ocenił jako „dobrą"

Nadzieje Bolesława Podhorskiego okazały się płonne. W 1918 r. dwór w Szlachowej został najechany przez chłopów z okolicznych wsi. Chłopi szlachowieccy poinformowali Józefa i Kazimierę Podhorskich, rodziców Bolesława, o zagrożeniu. Komitety wiejski i gminny zgodziły się, aby Podhorscy wyjechali z rzeczami osobistymi na 12 saniach. Transport ten został jednak zatrzymany i rozgrabiony, ale Podhorscy uratowali się i szczęśliwie dotarli do Złotopola, gdzie później przyjechał i ich syn Bolesław. W tym samym czasie (styczeń 1918 r.) ogród, dwór i stajnia zostały spustoszone i zrabowane ${ }^{98}$.

W okresie tymczasowości przypadającej między zakończeniem fal pogromów dworów z przełomu 1917 i 1918 r. a pokojem ryskim z 1921 r. ziemianie przyjmowali różne postawy. W 1918 r. sytuację uspokoiła okupacja Ukrainy przez Państwa Centralne, z ulgą przyjęta przez miejscowe ziemiaństwo, na co zwrócił uwagę Zygmunt Podhorski:

Dzięki okupacji wojskowej ustały napady i rabunki dworów, ale wybuchały lokalne powstania i ruchawki, które zmuszały władze okupacyjne do skupiania swych oddziałów po miastach. Najczęściej występowały te ruchawki w taraszczańskim powiecie, gdzie leżały nasze majątki. Niemcom zależało na tym, aby z żyznej Ukrainy wyciągnąć jak najwięcej zboża i produktów rolnych. Zaczęli więc dopingować ziemian, aby odbudowali zniszczone majątki i cukrownie i powadzili dalej zasiewy i gospodarkę

\footnotetext{
95 B. Podhorski, Pogrom dworu, s. 27-28.

96 Tamże, s. 28.

97 Tamże, s. 26-27.

Tamże, s. 29-31. 
Niektórzy, jak na przykład Bolesław Podhorski, starali się odbudowywać swoje majątki. Już miesiąc po pogromie, 20 II 1918 r., Bolesław Podhorski powrócił do rodzinnego majątku w Szlachowej, ocenił szkody, spotkał się ze starszyzną wiejską. Nie mogąc przeprowadzić prac wiosennych i zasiewów, przekazał chłopom „na spółkę” część gruntów. Zamieszkał w Szlachowej i starał się odbudowywać gospodarstwo. Udało mu się zebrać i sprzedać zbiory w 1918 r. ${ }^{100}$

Inni ziemianie nie starali się łagodzić napięć społecznych na wsi, lecz ukarać sprawców pogromów przy pomocy wojsk niemieckich i austro-węgierskich. Takie działania zostały skrytykowane przez Zygmunta Podhorskiego:

Niestety, niektórzy posunęli się tak daleko, ze wykorzystywali oddziały niemieckie i austriackie dla wymuszenia siłą zwrotu rozgrabionego inwentarza, względnie zapłaty w gotówce za poczynione szkody. Wprowadzało to ostre zadrażnienia i podcinało wszelkie nadzieje na możliwość jakiej takiej ugody na przyszłość. Takie krótkowzroczne załatwienie rachunków miało raczej charakter zemsty, a nie sprawiedliwego wyegzekwowania należności za poczynione szkody. Rozprawy takie nie były powszechne, a choć odosobnione, nie mniej jednak rzucały cień na ogół ziemian ${ }^{101}$.

W obliczu zakończenia pierwszej wojny światowej, upadku Państw Centralnych, a także rozkładu ich sił zbrojnych na okupowanych terenach Ukrainy i działań wojsk bolszewickich nie była możliwa dalsza obecność polskich właścicieli ziemskich. Szukali oni schronienia w odradzającej się Rzeczypospolitej. W 1918 r. Bolesław Podhorski ponownie musiał uciekać z Szlachowej, próbował przebijać się na zachód z oddziałem partyzanckim, który jednak został rozbity. Bolesław Podhorski i jego rodzice dotarli do Polski dopiero pod koniec 1919 r. ${ }^{102} \mathrm{Z}$ kolei Wacław Podhorski przybył do Warszawy w $1918 \mathrm{r}$.:

Warunki, w których się znalazłem po przybyciu do Warszawy początkowo nie różniły się niczym od reszty naszych wysiedlonych kresowców. Dopiero po traktacie ryskim, gdy posiadane przez nas na Polesiu dobra weszły ostatecznie w granice Polski, odzyskałem grunt pod nogami i możność dopomożenia bliższej i dalszej rodzinie ${ }^{103}$.

100

B. Podhorski, Pogrom dworu, s. 30-31.

Z. Podhorski, Społeczeństwo polskie, s. 158.

B. Podhorski, Pogrom dworu, s. 30-31.

W. Podhorski, Moje ostatnie wspomnienia, s. 133. 
W 1920 r. zgłosił się jako ochotnik do Wojska Polskiego i służył w ochotniczej formacji jazdy, a mianowicie w 214. pułku ułanów Armii Ochotniczej, dowodzonym przez pułkownika Tadeusza Żółkiewskiego. W wojnie polsko-bolszewickiej walczył w rejonie Krasnegostawu, Zamościa i Kowla. Wacław Podhorski w Warszawie mieszkał aż do $1924 \mathrm{r}^{104}$

Wybuch Wielkiej Wojny zastał Baltazara Podhorskiego młodszego (1893-1945) na studiach w Kijowie. Mimo niesprzyjających okoliczności zaangażował się on w działalność harcerską:

W 1917 r. zetknąłem się z Harcerstwem i ideologia tego ruchu od razu przemówiła mi do przekonania. Wstąpiłem do ówczesnej organizacji harcerskiej, w której przechodziłem wszystkie szczeble do drużynowego włącznie, byłem również członkiem Sztabu Naczelnika Harcerstwa na Rusi i w Rosji. Wobec zawieruchy rewolucyjnej i wielokrotnie zmieniających się w Kijowie władz bolszewickich, ukraińskich, niemieckich - praca harcerska odbywała się w bardzo trudnych warunkach i jedynie wiara w celowość tej pracy, dążącej do odzyskania Niepodległości polski, dawała mi siły do wytrwania. W tym samym czasie z ramienia Harcerstwa współpracowałem z P.O.W. W czerwcu 1919 roku wyjechałem do kraju przewiozłem ze sobą przez front bolszewicko-polski dokumenty P.O.W. dla Naczelnego Dowództwa w Warszawie. Po przyjeździe do polski brałem udział w pracach harcerskich w Zakopanem, później w lipcu 1920 r. zgłosiłem się do harcerskich oddziałów ochotniczych ${ }^{105}$.

Na łamach swych wspomnień Piotr Podhorski i Wacław Podhorski nie przekazali informacji o losach swych majątków i domów w latach 1917-1921, ale pozostawili ogólne refleksje na temat zagłady polskiego ziemiaństwa na wschód od granicy ryskiej. W swych wspomnieniach Wacław Podhorski starał się ograniczać osobiste przeżycia do minimum, umieszczał je, aby naświetlić szersze zjawiska historyczne ${ }^{106}$.

W opinii Wacława Podhorskiego kresowe ziemiaństwo zafascynowało odradzanie się wolnej Polski:

Gdy siła wyższa zmusiła nas do opuszczenia tego kraju, który tak kochaliśmy, byliśmy miotani najrozmaitszymi uczuciami. Przede wszystkim byliśmy

\footnotetext{
104 Tamże, s. 134.

105 Oświadczenie red. B. Podhorskiego, złożone Sądowi Okręgowemu, [w:] O chrześcijański i polski charakter harcerstwa: sprawozdanie z procesu redaktora odpowiedzialnego "Strażnicy Harcerskiej" w Sądzie Okręgowym w Warszawie w dniach 1 grudnia 1934 r. i 28/29 marca 1935 r., Warszawa 1935, s. 29.

Tamże, s. 130.
} 
urzeczeni nimbem odradzającej się ojczyzny, o której wszyscy od dzieciństwa śniliśmy. To uczucie w dużej mierze zacierało w nas wrażenie utraty dachu nad głową i podstaw naszej egzystencji. Co prawda nikt z nas wtedy jeszcze nie zdawał sobie sprawy, że stanęliśmy w obliczu faktu nieodwracalnych ${ }^{107}$.

W dalszej części swych wspomnień Wacław Podhorski pisał, że jego środowisko było przekonane, iż zamieszkanie w granicach II Rzeczypospolitej było przejściowe:

Wszyscy bez wyjątku opuszczając nasz kraj byliśmy najmocniej przekonani, że nie opuszczamy go na zawsze. Osiedlenie się nasze w granicach odradzającej się Rzeczypospolitej traktowaliśmy tylko jako czasowy etap. Byliśmy zupełnie pewni, że ten kraj, który opuściliśmy, ta integralna część dawnej Rzeczypospolitej musi prędzej czy później powrócić do macierzy, a my wtedy tam powrócimy i odbudujemy zniszczone nasze siedziby i warsztaty pracy. Nie mogło nikomu u nas w głowie się pomieścić, że zaszły tak nieodwracalne fakty ${ }^{108}$.

Opinie Wacława Podhorskiego potwierdzają informacje innych ziemiańskich memuarystów o zaskoczeniu, z jakim przyjęto zagładę polskiej większej własności ziemskiej na Ukrainie. Piotr Podhorski wspominat: „Niemniej ten okres 1912-1914 r. przypominał ciszę przed burzą, ale nikt nie przewidywał, że w 1918 roku własność polska na Ukrainie przestanie w ogóle istnieć” ${ }^{109}$.

Nadzieje na powrót w rodzinne strony rozwiały wydarzenia z lat 1920-1921, a mianowicie nieudana wyprawa kijowska, konieczność obrony niepodległości w wojnie z Rosją bolszewicką, pokój ryski oraz ustalenie wschodnich granic Polski. Wówczas to większość ziemian „otworzyła oczy na stan faktyczny”, przeszła „ze stanu prowizorium" do trzeźwej oceny nowej sytuacji, w której w granicach Polski nie znalazły się ich rodzinne ziemie. Najgorzej zniosło to starsze pokolenie ziemiańskiego środowiska; Wacław Podhorski pisal, że ludzie ci „wegetowali” w „bardzo ciężkich warunkach materialnych i moralnych" ${ }^{110}$. Piotr Podhorski natomiast podawal przykład swego ojca:

Ś.P. Ojciec nasz po śmierci drugiej żony - jeszcze na Ukrainie, załamał się, a przejścia 1917-1918 r. całkowicie Go wykoleiły i w wieku lat 65-ciu bezmała stał się zgrzybiałym staruszkiem i chociaż zachował pełną umysłowość - jednak nie mógł się dostosować do tak odmiennych warunków życia. Zawsze przyzwy-

107 108 109 110

Tamże, s. 131.

Tamże.

P. Podhorski, Moje wspomnienia, t. 1, s. 78.

W. Podhorski, Moje ostatnie wspomnienia, s. 132-133. 
czajony był do normalnego i ustabilizowanego traktowania spraw, a nie do borykania się z losem w tak odmiennych warunkach ${ }^{111}$.

Stopniowo ziemiaństwo kresowe zaczęło się usamodzielniać, podejmować prace zarobkowe, żyć własnym życiem. W przypadku rodziny Wacława Podhorskiego traktat ryski w pewien sposób pozwolił na odzyskanie gruntu pod nogami, ponieważ posiadane przez nich dobra poleskie znalazły się w granicach państwa polskiego i dały możliwość zachowania przez rodzinę statusu właścicieli ziemskich ${ }^{112}$.

W 1930 r. bracia Podhorscy dysponowali na Polesiu dwoma majątkami: Radyżewo o powierzchni 120 ha i znacznie większy Chinocz - 5129 ha $^{113}$. Dobra te były ich wspólną własnością, administrowane przez Wacława. Majątek Chinocz w czasie wojen z lat 1914-1921 uniknął większych zniszczeń, ale wymagał nowych i kosztownych inwestycji. Jak wspominał Wacław Podhorski:

Inwentarze żywe i martwe właściwie nie egzystowały. Ziemie orne zostały podzielone i uprawiane przez miejscową ludność. Łąki bliższe osiedli były normalne koszone i w[y]korzystywane przez tę samą ludność. Dalsze od osiedli łąki w ogóle koszone nie były i porosły lasem. Na miejscach dawniej kośnych łąk tokowały głuszce.

O drzewostanach w najbliższym sąsiedztwie wsi szkoda nawet wspominać. Wszystko co nadawało się na budulec było wyrąbane. W dalej położonych partiach lasu drzewostany nietknięte i jak się później okazało drzewostany olchy przekroczyły wiek eksploatacyjny. Z drewna wyrąbanego wielu się pobudowało nie tylko na swoich działkach, ale i na zajętych dworskich ${ }^{114}$.

W tej sytuacji Podhorski planował sprzedaż majątku, ale ostatecznie do tego nie doszło. Lata międzywojnia spędził na administrowaniu majątkami i rozwijaniu swojej łowieckiej pasji.

W okresie międzywojennym poleskie dobra Podhorskich zostały objęte ustawą o reformie rolnej. Wyznaczono kontyngent ziemi, która powinna być rozparcelowana. Wacław Podhorski sprowadził w tym celu kolonistów z Radomskiego ${ }^{115}$.

\footnotetext{
111 P. Podhorski, Moje wspomnienia, t. 2, s. 21.

112 W. Podhorski, Moje ostatnie wspomnienia, s. 133.

113 Spis ziemian Rzeczypospolitej Polskiej w roku 1930. Województwo poleskie, województwo wotyńskie, oprac. T. Epsztein, S. Górzyński, Warszawa 1996, s. 27.

114 W. Podhorski, Moje ostatnie wspomnienia, s. 254.

115 Tamże, s. 243.
} 
Kolejnym problemem, który był zmuszony rozwiązać, były serwituty. Zostały one wykupione w zamian za grunty, które otrzymali miejscowi chłopi ${ }^{116}$.

Podsumowując, w losach kilku przedstawicieli rodu Podhorskich jak w zwierciadle odbijały się dzieje ziemiaństwa polskiego z Wołynia, Podola i Kijowszczyny w latach 1914-1921. Przed wybuchem Wielkiej Wojny wiedli oni spokojne i dostatnie życie właścicieli ziemskich. W latach 1917-1921 utracili rodzinne gniazda i majątki, które po traktacie ryskim znalazły się w granicach Rosji radzieckiej. Podhorscy, jak wielu kresowych ziemian, szukali schronienia i nowego startu życiowego w odrodzonej Polsce. Problemy, z jakimi borykali się dawni Kresowiacy, trafnie i plastycznie opisała Maria Dunin-Kozicka:

a iluż to wygnańców przyjechało do Polski w wieku podeszłym, gdy zużyte sily domagają się wypoczynku, a nie wyczerpującej i rozpaczliwej pogoni za możnością znalezienia zarobku. Pomimo to kresowcy nie stracili energii. Niektórzy wnet po przyjeździe do Warszawy otworzyli tu restauracje i kawiarnie, jako przedsiębiorstwa akcyjne, gdzie kelnerkami zostały ziemianki kresowe. Ze względu na pochodzenie swych pracowników zakłady te mają bezsprzeczne prawo do przybrania nazwy „Ziemiańskich”, „Kresowych”. Najlepiej powodzi się wszelkiego rodzaju fachowcom, najgorzej - rolnikom. Ziemia polska nie jest bowiem tak rozległa, żeby mogła dać posady rolne własnym i napływowym pracownikom. Ci tedy z musu obrali sobie inne tereny działalności, stworzyli związki handlowe, syndykaty rolnicze, pracują po bankach, po sklepach, mierzą, ważą, stukają na maszynach i... żyją! Mogą nawet - chociaż z bezmiernym wysiłkiem - wychowywać i kształcić dzieci ${ }^{117}$.

$\mathrm{Z}$ trzech braci Podhorskich tradycje ziemiańskie kontynuował Wacław, zostając administratorem rodzinnego majątku na Polesiu. Pozostali dwaj, Zygmunt i Włodzimierz, poświęcili się karierze wojskowej, zostając zawodowymi żołnierzami.

Włodzimierz Podhorski w 1919 r. wstąpił do Wojska Polskiego, brał udział w wojnie polsko-bolszewickiej, a później został dowódcą 17. Pułku Ułanów Wielkopolskich. W czasie przewrotu majowego okazał lojalność ówczesnemu rządowi i został zdymisjonowany w randze pułkownika rezerwy. Wedle relacji Piotra Podhorskiego w latach 1926-1939 mieszkał w Poznaniu i pracował w Towarzystwie Ubezpieczeń „Vesta” oraz jako zarządca przymusowy majątków ziemskich ${ }^{118}$. Eugeniusz

\footnotetext{
116 Tamże, s. 259.

117 M. Dunin-Kozicka, Burza od wschodu, s. 271.

118 Uzupetnienia do Monografii, k. 22-23; J. Wasiutyński, Zarys historii wojennej 17-go Pułku Ułanów Gnieźnieńskich, Warszawa 1929, s. 5.
} 
Śliwiński natomiast w swym biogramie pułkownika podał, że w latach 1921-1929 pełnił funkcję dowódcy 17. Pułku Ułanów, a w 1929 r. został przydzielony do Wojskowego Trybunału Orzekającego w Modlinie. W 1933 r. został przeniesiony w stan spoczynku. Mieszkał w Poznaniu do wybuchu drugiej wojny światowej ${ }^{119}$.

Zygmunt Podhorski na początku lat dwudziestych XX w. był inicjatorem osadnictwa wojskowego na Kresach Wschodnich. W okresie międzywojennym dowodził Centrum Wyszkolenia Kawalerii w Grudziądzu, 13. Brygadą Kawalerii, a następnie Suwalską Brygadą Kawalerii ${ }^{120}$.

Bolesław Podhorski wraz z rodzicami od listopada 1919 r. mieszkał w Polsce. W 1920 r. wstąpił do wojska, służył w 1. Pułku Ułanów Krechowieckich, którego dowódcą był jego kuzyn Zygmunt Podhorski. Od 1921 r. Bolesław uczestniczył w tworzeniu osadnictwa wojskowego na Wołyniu. Zaangażowany był w powstanie i rozwój Osady Krechowieckiej. Był wieloletnim prezesem Osady Krechowieckiej i wójtem gminy Aleksandria na Wołyniu. Uczestniczył w życiu społecznym i politycznym Wołynia. Był członkiem Wołyńskiej Izby Rolniczej, z której ramienia organizował kursy rolnicze. Działał w Wołyńskim Związku Szlachty Zagrodowej i Związku Osadników. Był autorem publikacji Zagadnienia społeczeństwa i państwa polskiego na Wołyniu, wydanej w Poznaniu w 1938 r. Związany był z miesięcznikiem „Awangarda Państwa Narodowego", był krytykiem polityki współpracy polsko-ukraińskiej realizowanej przez wojewodę wołyńskiego Henryka Józewskiego ${ }^{121}$. W Osadzie Krechowieckiej zamieszkał również Józef Podhorski.

Inny z przedstawicieli rodziny Podhorskich, Felicjan, brat Józefa, osiadł w Bydgoszczy i pracował w biurze gazowni oraz miejskim zarządzie wodociągów i kanalizacji ${ }^{122}$. Zmarł w 1935 r., a na miejsce wiecznego spoczynku odprowadziła go „garstka przyjaciół i kresowców”. Jak pisał „Dziennik Bydgoski”: „Nie było ani szumnej muzyki, ani tłumu ludzi, ani bogatych zaprzęgów - tak umarł dziedzic, ongiś bogaty pan, potomek jednej z najstarszych rodzin polskich na Ukrainie" ${ }^{123}$. W tym miejscu

119 E. Śliwiński, Podhorski Wtodzimierz Zygmunt (1884-1941), [w: ] Ludzie pierwszych lat niepodległości Leszna, Przyjaciel Ludu, Z. I/XCIV (2020), s. 16-17.

120 M. Krwawicz, W. Chrząszczewski, Podhorski Zygmunt, [w: ] PSB, t. 27, Wrocław-Warszawa-Kraków-Gdańsk-Łódź 1983, s. 102-103.

121 M. z Podhorskich Reyowa, A. Rey, Podhorski Bolesław, [w: ] Ziemianie polscy XX wieku, s. 117-119; J. Stobniak-Smogorzewska, Kresowe osadnictwo wojskowe 1920-1945, Warszawa 2003, s. 209.

122 Kurier Bydgoski, 3 VII 1935, nr 151, s. 10.

123 Dziennik Bydgoski, 10 VII 1935, nr 156, s. 8. 
należy dodać, że w okresie międzywojennym w grodzie nad Brdą zamieszkało wielu uchodźców z Kresów, m.in. Edward Wojniłłowcz ${ }^{124}$.

Podhorscy z Łopatyna, Baltazar senior (1863-1941) i jego syn Baltazar junior osiedli w Warszawie. Młodszy z Podhorskich kontynuował działalność harcerską. Pracował w Głównej Kwaterze Harcerskiej. W 1930 r. został sekretarzem Głównej Kwatery Męskiej Związku Harcerstwa Polskiego, lecz w roku następnym zrezygnował z tego stanowiska. W latach 1933-1934 był redaktorem czasopisma „Strażnica Harcerska”. Od 1926 r. zaangażował się w działalność antykomunistyczną. W latach trzydziestych był sekretarzem Centralnego Biura Porozumienia Organizacji Współdziałających w Zwalczaniu Komunizmu. Na łamach pisma „Biuletyn Informacyjny - Prawda o Komunizmie” opublikował dwa artykuły: „Na czerwonej fali” i „Udział Żydów w rewolucji komunistycznej w Rosji” ${ }^{125}$. Publikował również na łamach miesięcznika „Walka z Bolszewizmem” (artykuły: „Kolektywizacja rolnictwa w Sowietach „Sowiety rozpoczęly ofensywę ekonomiczną przeciwko Polsce” w tomie IV z 1930 r., „Niewola robotnika w Sowietach” w tomie V z 1931 r. ${ }^{126}$

Ostateczny kres rodzinie Podhorskich jako właścicielom ziemskim przyniosła druga wojna światowa. Polesie i tamtejszy majątek ziemski Wacława, Zygmunta i Włodzimierza Podhorskich znalazł się w granicach ZSRR. Włodzimierz Podhorski po wybuchu drugiej wojny światowej wstąpił do wojska, a po zakończeniu kampanii wrześniowej został jeńcem wojennym. Z powodu ciężkiej choroby został przewieziony z oflagu do Warszawy, gdzie zmar1 ${ }^{127}$. Zygmunt Podhorski w czasie kampanii wrześniowej dowodził Suwalską Brygadą Kawalerii, z którą przeszedł szlak bojowy

124 G. Chmielewska, W mieście nad Brdą byt „mały Kijów”, Gazeta Pomorska, 17 IX 2015, wersja on-line https://pomorska.pl/w-miescie-nad-brda-byl-maly-kijow/ar/8015151 [dostęp: 15 VI 2020]. Edward Wojniłłowicz tak opisał przyjazd do Bydgoszczy w 1921 r.: „Stanąłem w Bydgoszczy w mieszkaniu przez żonę moją najętym, gdzie prawdopodobnie życia dokonać nam wypadnie, bo jak świadczą dochodzące do nas wiadomości z kresów, bolszewicy nigdzie piędzi ziemi ustępować nam nie chcą, a nasi są bezsilni”, E. Wojniłłowicz, Wspomnienia 1847-1928. Część II, Warszawa 2016, s. 28.

125 K. Sacewicz, Rewolucja komunistyczna i dyktatura proletariatu w świetle publikacji Centralnego Porozumienia Organizacji Wspótdziałających w Zwalczaniu Komunizmu, Pamięć i Sprawiedliwość 30 (2017), nr 2, s. 71; T. Piotrowski, Poland's Holocaust. Ethnic Strife, Collaboration with Occupying Forces and Genocide in the Second Republic, 1918-1947, Jefferson, NC-London, 1998, s. 307.

126 Walka z Bolszewizmem V (1931), z. 34, s. 20, 21, 26; Oświadczenie red. B. Podhorskiego, s. 29-30.

127 Uzupetnienia do Monografii, k. 22-23. 
od Zambrowa i Czyżewa po bitwę pod Kockiem. Po kapitulacji Samodzielnej Grupy Operacyjnej „Polesie” trafil do niemieckiej niewoli. Po uwolnieniu w 1945 r. rozpoczął służbę w Polskich Sił Zbrojnych na Zachodzie. Po demobilizacji zamieszkał w Londynie ${ }^{128}$. W $1940 \mathrm{r}$. Wacław Podhorski wyjechał z Polesia ${ }^{129}$. Po drugiej wojnie światowej osiadł w Krakowie i podjął pracę w firmie „Zagon”130. Zmarł 26 VII 1966 r. po długiej chorobie i został pochowany na Cmentarzu Rakowickim ${ }^{131}$. Z kolei Piotr Podhorski wojnę i okupację przeżył w Warszawie, gdzie zmarł w 1970 r. ${ }^{132}$

Bolesław Podhorski walczył w kampanii wrześniowej i dostał się do niemieckiej niewoli. Po uwolnieniu z oflagu wstąpił do II Korpusu gen. Władysława Andersa. Po wojnie przebywał na emigracji do 1957 r., kiedy to zdecydował się wrócić do kraju. Zmarł w Warszawie w 1979 r. ${ }^{133}$ Baltazar Podhorski po upadku powstania warszawskiego został wywieziony do podobozu Hersbruck, będącego częścią obozu koncentracyjnego Flossenbürg, gdzie zmarł na początku stycznia 1945 r. ${ }^{134}$

Podhorscy nigdy już nie wrócili w rodzinne strony, a ich groby rozsiane są po całej Europie: Kraków (Wacław), Warszawa (Zygmunt), Bydgoszcz, gdzie znajdował się niezachowany do dziś grób Felicjana, bo - jak pisze Gizela Chmielewska - „nie znalazł się w Bydgoszczy nikt, kto by o to miejsce zadbał, kto by upomniał się o jego pamięć. Tym samym grób Podhorskiego w naszym mieście podzielił smutny los jego rodzinnych nekropolii na dalekiej Ukrainie ${ }^{135 ”}$.

\footnotetext{
128 M. Krwawicz, W. Chrząszczewski, Podhorski Zygmunt, s. 103-105.

129 W. Podhorski, Moje ostatnie wspomnienia, s. 272.

130 Tamże, s. 10.

131 Dziennik Polski, 26 VII 1966, nr 175, s. 4.

132 T. Epsztein, Wprowadzenie, s. 51.

133 M. z Podhorskich Reyowa, A. Rey, Podhorski Bolestaw, s. 119-122.

134 Tamże, cz. 7, Warszawa 2004, s. XVI; Lists of Inmates at Concentration Camp Flossenbürg - Men, nos. 20 000-34 999 (Book No. 3, vol. 122), https://catalog.archives.gov/id/73995853 [dostęp: 3 VII 2020]; Księga zmarłych obozu koncentracyjnego Flossenbürg, https://www. gedenkstaette-flossenbuerg.de/pl/badania/ksi\%C4\%99ga-zmar\%C5\%82ych [dostęp: 3 VII 2020].

135 Chmielewska G., Potomek ruskich kniaziów, wnuk powstańców styczniowych i inni, Gazeta Pomorska, 2 XII 2012, https://pomorska.pl/potomek-ruskich-kniaziow-wnuk-powstancow-styczniowych-i-inni/ar/7319845 [dostęp: 15 VI 2020].
} 


\section{Summary}

The article presents the history of the Podhorski family which, before the outbreak of WWI, owned numerous estates in Kiev governorate of the Russian Empire and lost them in the October Revolution, wars (the civil war in Russia, the Polish-Soviet war) and the Peace of Riga as a result of which the Kiev region was incorporated into the USS. Most attention has been devoted to the life stories of diarists Piotr Podhorski, Wacław Podhorski, Zygmunt and Bolesław Podhorski. Before 1914, they were members of the social elite, the landed gentry. In the Interim period, they were immigrants in Poland, forced to find a new home and work. However, brothers Wacław, Zygmunt and Włodzimierz Podhorski kept their estate in Polesie voivodeship, administered by Wacław while his brothers chose to be professional soldiers. On the other hand, Piotr Podhorski worked in banks and insurance companies. Bolesław Podhorski was involved in military settlement in Volhynia. Neither of them ever returned to their fatherland in Ukraine or to their homes from the Interwar period because after WWII, Polesie and Volhynia were left outside of Poland's borders. Consequently, the Podhorskis lost their fatherland, home and estate twice: first during WWI and later on in the course of WWII.

Nadesłany 31 III 2020

Nadesłany po poprawkach recenzyjnych 27 VII 2020

Zaakceptowany 29 VII 2020

Prof. UJ dr hab. Tomasz Kargol

Instytut Historii Uniwersytetu Jagiellońskiego w Krakowie

ul. Gołębia 13

31-007 Kraków

tomasz.kargol@uj.edu.pl 
Nagrobek Wacława Podhorskiego na Cmentarzu Rakowickim w Krakowie, 2017, fot. T. Kargol

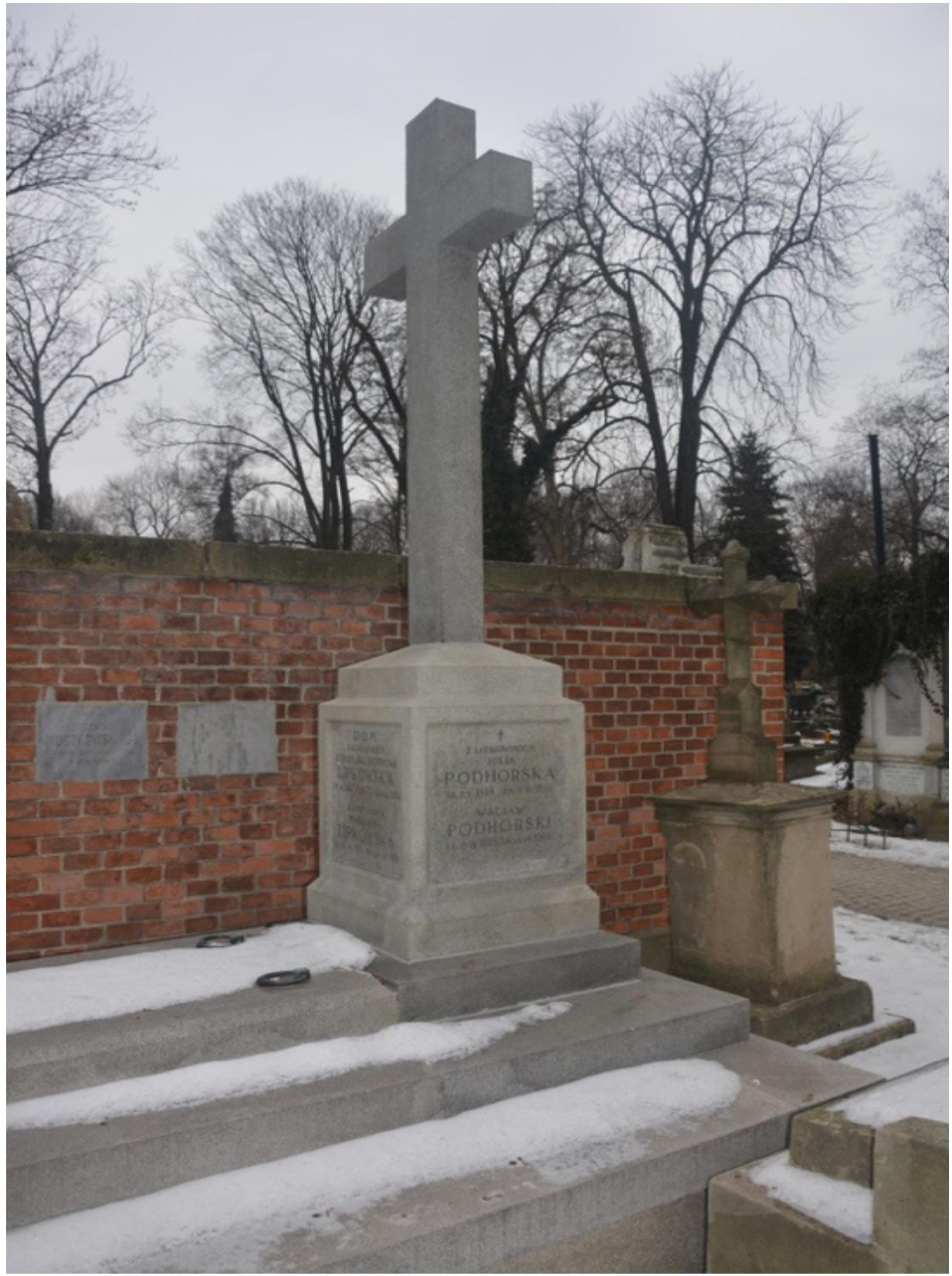

